\title{
Autochthonous Georgian and Dagestan grapevine varieties on the collection in the Rostov region
}

\author{
Valentina Ganich ${ }^{1}$ and Lyudmila Naumova ${ }^{1, *}$ \\ ${ }^{1}$ All-Russian Research Institute named after Ya.I. Potapenko for Viticulture and Winemaking - \\ branch of Federal State Budget Scientific Institution «Federal Rostov Agricultural Research Center», \\ Baklanovsky Avenue, 166, Novocherkassk, Rostov region, 346421, Russia
}

\begin{abstract}
The purpose of the research was to study 8 Georgian and 3 Dagestan technical autochthonous grapevine varieties and identify the most productive and promising ones for high-quality winemaking in the Rostov region. The research was conducted in 2016-2019 at Don ampelographic collection named after Ya.I. Potapenko (Novocherkassk, Russia) according to generally accepted methods and state Standards in viticulture. Don autochthonous varieties Sibirkovyij and Krasnostop zolotovskij were used as controls. The soil - ordinary Chernozem carbonate. All the studied varieties had a high percentage of bud break (from $69.3 \%$ in Hotsa tsibil to $81.2 \%$ in Mahbor tsibil). The fruiting coefficient of 1.0 or more was observed in 6 varieties. The average weight of a bunch varied from $74 \mathrm{~g}$ (Mudzhuretuli) to $459 \mathrm{~g}$ (Adreuli shavi). The estimated yield was very high for the varieties - Adreuli shavi and Nakutvneuli, high - Goruli mtsvane, Hotsa tsibil, medium - Latsu kere, Grdzelmtevana, Grubela, Amlakhu, Sibirkovyij, Vernakhi and Krasnostop zolotovskij. Grapevine varieties Goruli mtsvane, Grdzelmtevana, Grubela, Latsu kere, Hotsa tsibil, Nakutvneuli were selected as prospective due to agronomic traits and high quality of wine. These varieties are also recommended to be used in breeding for creating varieties with high technological properties for highquality winemaking.
\end{abstract}

\section{Introduction}

Genetic diversity, natural or man-made, is the basis for developing new varieties of cultivated crops, including grapevine. The greatest value and great pride of viticulture of any country are autochthonous varieties cultivated for production. Working with such varieties makes it possible to do the country's winemaking quite distinctive; only wines from autochthonous varieties can create a recognizable and unique style of the winemaking region. In the assortment of countries with developed viticulture, a significant place is occupied by ancient, traditionally cultivated grapevine varieties with valuable economic characteristics, adapted to the agro-ecological conditions of the region. Much attention is

\footnotetext{
*Corresponding author: LGnaumova@yandex.ru
} 
paid to the conservation and study of varieties of this group. They often carry genes valuable for breeding that may be required at a certain stage [1-4].

Large-scale studies are being carried out aimed at comparative analysis, study, identification of genotypes of autochthonous varieties and clones of grapevines using the method of microsatellite (SSR) markers. Microsatellite markers used to differentiate grapevine specimens can effectively complement ampelographic characteristics and are generally used as an advanced molecular management tool within the Vitis genetic resource collection, such as identification and distinction of genotypes, study of genetic diversity, collection creation, study genealogy and verification. These studies allow identifying synonyms, confirming or refuting the previously assumed relationship with varieties from other countries and regions, clarifying the origin (parental forms) of a variety, and proving genetic similarity between autochthonous varieties [5-12].

To solve theoretical and applied problems in breeding, the gene pool of culture is the fundamental basis. Autochthonous grapevine varieties are the most valuable part of the world's gene pool. The main method of conserving plant genetic resources today is field collections. Mobilization of genetic resources in ampelographic collections of different countries of the world is important for the preservation, replenishment and study of the grape gene pool.

Eastern European, Caucasian and Central Asian countries are a source of interesting biodiversity. There are more than 500 Georgian autochthonous varieties, they occupy $95 \%$ of the vineyard area of their country, and produce quality wines that are highly appreciated all over the world, they are also a source of biodiversity and resistance to various climate changes [13-14]. In the conditions of Northern Italy, 134 Georgian local varieties were studied. Studies have shown that the dates of the onset of the phenological phases of budding and flowering, as well as the ripening period of these varieties, were a bit later than other Western European varieties. Some of the studied Georgian varieties could not reach technological maturity under these growing conditions [15].

There are more than 150 Dagestan local varieties, and many of them are used for the production of high-quality table, liqueur wines and cognacs.

Studies of the germplasm of grapevine from the Caucasus region have shown that these varieties are distinguished by high genetic and morphological diversity.

The first ampelographic collection in the Rostov region was established before 1938, mainly of native Don varieties. The uniqueness of the existing ampelographic collection is in the fact that it is located in the area of sheltered viticulture. Rostov region is famous for its well-known high-quality Don wines - Sibirkovyij, Krasnostop zolotovskiy, Tsimlyanskij cherhij, Plechistik, Kumshatskij. Continuation of the ongoing research will make it possible to point out new samples with the same high technological properties for high-quality winemaking from the number of narrow spread and rare collectional varieties.

The Don ampelographic collection currently contains 100 native grapevine varieties from various Caucasian regions: the largest number from Georgia - 44 (Aleksandrouli, Beglaris kurdzeni, Berbesho, Buera, Gabekhoura shavi, Goruli mtsvane, Grubela, Rkatsiteli, Saperavi, Khihvi, etc.), Dagestan - 38 (Agadai, Budaij shuli, Gimra, Gezendai, Gkhara bakhint sibil, Hop khalat, etc.); from Armenia - 12 (Voskeat, Garandmak, Yezandari belij, Yezandari cherhij, Kahet, etc.), from Azerbaijan - 6 (Bayan shirey, Shaani cherhij, Shirvan shakhi, etc.). The study of agrobiological, technological and economically valuable traits of varieties in ampelographic collections is a continuous process. As a result, varieties will be selected that are resistant to various environmental factors (biotic and abiotic), meeting the modern market requirements, and will also be used for breeding in various research institutions and for the backyard farming. 
The purpose of the research was to study the Georgian and Dagestan autochthonous grapevine technical varieties, and the selection of the most productive and promising for high-quality winemaking in the climatic conditions of the Rostov region.

\section{Materials and methods}

The study was carried out on the ampelographic collection (Novocherkassk, Russia) in 2016 - 2019. 11 autochthonous wine varieties were studied: 8 Georgian (Adreuli shavi, Amlakhu, Mudzhuretuli, Nakutvneuli, Goruli mtsvane, Grubela, Grdzelmtevana, Vernakhi) and 3 Dagestan (Mahbor tsibil, Hotsa tsibil, Latsu kere). Don autochthonous varieties Sibirkovyij and Krasnostop zolotovskij - were used as reference varieties. The varieties are grown in a grafted culture (rootstock - Kober 5BB), covering, non-irrigated, with longsleeved formation, planting scheme $3.0 \times 1.5 \mathrm{~m}$.

The site is located on the Don steppe plateau, with a terrain height of $90 \mathrm{~m}$ above sea level and wavy relief. The soils are chernozems, which are part of the soil province of the Azov and Ciscaucasian chernozems, the humus layer is $3.5-4 \%$, not saline, have a high phosphorus content, medium - potassium and calcium. Groundwater is located at a depth of $15-20 \mathrm{~m}$ and is inaccessible to the root system of vines. The Rostov region is the northern border of the industrial cultivation of viticulture in the Russian Federation and is characterized by insufficient moisture and dry sultry summers. The winter period is unstable, with sharp changes in minus temperatures, with frequent thaws and severe frosts. Frosts occur in early autumn and late spring. Long-term sunlight contributes to the cultivation of grapevine in the region (in early autumn, when the grapes are ripening).

In the Rostov region, characterized by little snowy winters, vine bushes have to be covered for the winter to protect them from destructive low temperatures. The meteorological conditions of the Rostov region are optimal for realization of biological potential of most of the introduced autochthonous varieties.

The study of the varieties on the collection was carried out according to the methods generally accepted for viticulture and Russian Standard. Samples of wines were prepared in the laboratory of wine-making technology (micro-wine-making conditions) according to the classical technology for preparing table dry wines according to regulatory documents and Russian Standard. The wines were evaluated by the institute's tasting committee, approved by the order of the director, at closed scientific tastings according to Russian Standard 32051-2013 «Wine products. Methods of organoleptic analysis». Wine tasting scores are based on the data of the Wine Technology Laboratory.

\section{Results and Discussion}

Phenological phases are determined, first of all, by the biological characteristics of varieties and the conditions of the growing season. The weather conditions for the research were characterized as favorable (Table 1). Critical freezing temperatures were not observed in winter. The maximum temperature was recorded in the summer of 2018. 2019 was the longest growing season with the lowest rainfall. The latest date for the start of the growing season in 2017 is April 27.

Analyzing the data of phenological observations, we note that, on average, over 4 years of research, bud break in the conditions of the Rostov region took place in the period from April 21 to 23. Simultaneous bud breaking of grapevine varieties with different ripening periods can be explained by the fact that, regardless of the ripening period, all varieties in the initial phase of the growing season have almost the same biological requirements for environmental conditions, first of all, for the sum of active air temperatures. 
Table 1. Meteorological indicators in the years of observation

\begin{tabular}{|c|c|c|c|c|c|c|}
\hline \multirow[b]{2}{*}{ Years } & \multicolumn{4}{|c|}{ Vegetation period } & \multirow[b]{2}{*}{$\begin{array}{c}\text { Minimum } \\
\text { air } \\
\text { temperature } \\
{ }^{\circ} \mathrm{C}\end{array}$} & \multirow[b]{2}{*}{$\begin{array}{l}\text { Annual } \\
\text { precipita } \\
\text { tion, } \mathbf{m m}\end{array}$} \\
\hline & $\begin{array}{c}\text { days above } \\
\quad+10^{\circ} \mathrm{C}\end{array}$ & $\begin{array}{l}\text { number } \\
\text { of days }\end{array}$ & $\begin{array}{l}\text { sum of active } \\
\text { temperature } \\
\text { s, }{ }^{\circ} \mathrm{C}\end{array}$ & $\begin{array}{c}\text { maximum } \\
\text { air } \\
\text { temperatur } \\
\mathrm{e},{ }^{\circ} \mathrm{C}\end{array}$ & & \\
\hline 2016 & April 5 - October 10 & 188 & 3798 & 37.5 & -20.5 & 779.4 \\
\hline 2017 & April 27 - October 15 & 172 & 3560 & 39.0 & -18.9 & 452.9 \\
\hline 2018 & April 5 - October 26 & 204 & 4210 & 40.0 & -13.6 & 511.4 \\
\hline 2019 & April 7 - October 29 & 206 & 3927 & 37.2 & -11.5 & 403.3 \\
\hline \multicolumn{2}{|c|}{ Long-term average } & & 3361 & 41.0 & -31.3 & 533.8 \\
\hline
\end{tabular}

Having classified the varieties according to the duration of the production period, we note that the group of the early-middle ripening period (126-135 days) included varieties Latsu kere and Sibirkovyij; middle ripening period (136-145 days) - Grdzelmtevana, Grubela, Mudzhuretuli and Krasnostop zolotovskij; mid-late ripening period (146-155 days) - Hotsa tsibil, Goruli mtsvane, Amlakhu, Mahbor tsibil; late ripening period (156165 days) - Nakutvneuli, Vernakhi and Adreuli shavi (Table 2). The sums of active temperatures of growing seasons are sufficient for the ripening of grapes of the studied varieties in this region.

Table 2. Agrobiological indicators of grape varieties (average for 2016-2019)

\begin{tabular}{|c|c|c|c|c|c|c|}
\hline \multirow{2}{*}{ Variety } & \multirow{2}{*}{$\begin{array}{c}\text { Bud break, } \\
\%\end{array}$} & \multirow{2}{*}{$\begin{array}{c}\text { Fruitful } \\
\text { shoots, } \%\end{array}$} & \multirow{2}{*}{$\begin{array}{c}\text { Coefficient } \\
\text { fruiting }\end{array}$} & \multirow{2}{*}{$\begin{array}{l}\text { Average } \\
\text { bunch } \\
\text { weight, } \\
\text { g }\end{array}$} & \multicolumn{2}{|c|}{\begin{tabular}{|c|} 
From budding to \\
complete physiological \\
maturity
\end{tabular}} \\
\hline & & & & & $\begin{array}{c}\text { number } \\
\text { of days }\end{array}$ & $\begin{array}{c}\text { sum of active } \\
\text { temperatures } \\
{ }^{0} \mathrm{C}\end{array}$ \\
\hline \multicolumn{7}{|c|}{ Varieties with white berries } \\
\hline Goruli mtsvane & 71.6 & 69.5 & 1.0 & 280 & 152 & 3350 \\
\hline Grdzelmtevana & 75.8 & 46.3 & 0.6 & 371 & 140 & 3128 \\
\hline Grubela & 75.9 & 31.8 & 0.4 & 428 & 145 & 3218 \\
\hline Hotsa tsibil & 69.3 & 63.8 & 0.9 & 253 & 146 & 3272 \\
\hline Latsu kere & 77.1 & 82.7 & 1.3 & 178 & 134 & 3120 \\
\hline Sibirkovyij & 70.5 & 66.1 & 1.1 & 190 & 134 & 3041 \\
\hline \multicolumn{7}{|c|}{ Varieties with colored berries } \\
\hline Adreuli shavi & 80.1 & \begin{tabular}{|l|}
58.8 \\
\end{tabular} & $\begin{array}{l}0.7 \\
\end{array}$ & 459 & 160 & 3463 \\
\hline Amlakhu & 76.0 & 49.9 & 0.8 & 258 & 152 & 3350 \\
\hline Vernakhi & 74.1 & 65.3 & 0.9 & 229 & 158 & 3444 \\
\hline $\begin{array}{l}\text { Krasnostop } \\
\text { zolotovskij }\end{array}$ & 71.6 & 69.2 & 1.0 & 140 & 145 & 3250 \\
\hline Mahbor tsibil & 81.2 & 30.7 & 0.4 & 245 & 155 & 3401 \\
\hline Mudzhuretuli & 80.3 & 66.1 & 1.1 & 74 & 145 & 3216 \\
\hline Nakutvneuli & 70.0 & 73.0 & 1.2 & 221 & 156 & 3403 \\
\hline $\mathrm{LSD}_{0,95}$ & & 18.4 & 0.3 & 75.6 & & \\
\hline
\end{tabular}

According to the data of agrobiological surveys, on average over the years of research, all studied varieties had high percentage of bud break (from $69.3 \%$ for the Hotsa tsibil variety to $81.2 \%$ for the Mahbor tsibil variety). Varieties Adreuli shavi, Mudzhuretuli, Mahbor tsibil had bud break more than $80 \%$. 
The fruitfulness of the shoots depends on the genetic characteristics of the variety. The weather conditions of the year and the level of agricultural technology have a significant impact on the percentage of fruiting shoots. Two varieties Latsu kere and Nakutvneuli had more than 70 percent of fruiting shoots. The lowest rate of fruiting shoots (at the level of 30.7-31.8\%) had varieties Mahbor tsibil and Grubela.

An indicator - fruiting coefficient of 1.0 or more was observed in 6 varieties (Latsu kere, Nakutvneuli, Sibirkovyij, Mudzhuretuli, Goruli mtsvane, Krasnostop zolotovskij).

The mass of a bunch and productivity of the shoot mainly determine the yield of the variety. The average bunch weight in the studied varieties varied from $74 \mathrm{~g}$ (Mudzhuretuli) to $459 \mathrm{~g}$ (Adreuli shavi). Most of the studied Georgian varieties have a high average bunch weight (Adreuli shavi - 459 g, Grubela - 428 g, Grdzelmtevana - 371 g, Goruli mtsvane $280 \mathrm{~g}$ ). In some years, the maximum weight of a bunch in some varieties reaches 800 1200 g (Grdzelmtevana, Grubela, Andreuli shavi). Hotsa tsibil variety had the largest average bunch weight $(253 \mathrm{~g})$ of the Dagestan varieties. The control varieties had an average bunch weight from $140 \mathrm{~g}$ (Krasnostop zolotovskij) to $190 \mathrm{~g}$ (Sibirkovyij). Figure 1 shows the varieties with the largest bunch mass - the Georgian variety Grdzemtevana and the Dagestan - Hotsa tsibil.

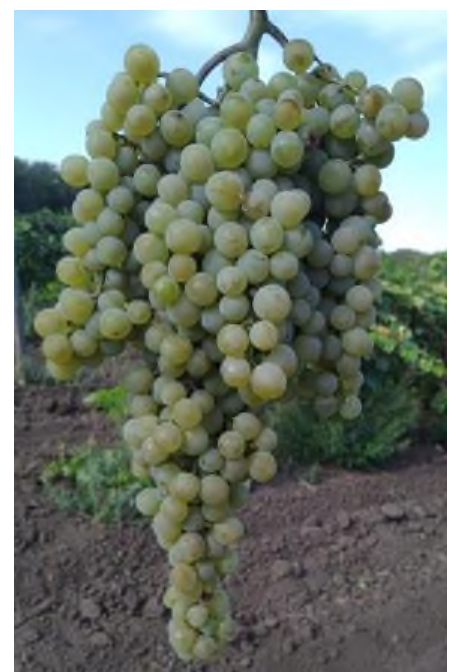

A

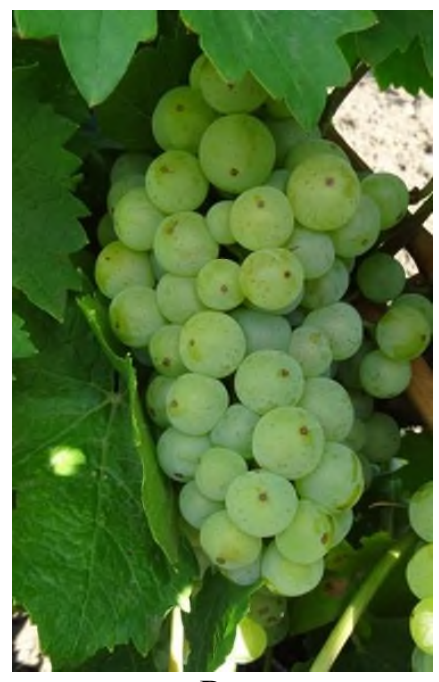

$\mathrm{B}$

Fig. 1. Bunches of grape varieties: A - Grdzelmtevan; B - Hotsa tsibil

An objective assessment of the productivity of grapevine is one of the most important tasks of varietal study. The yield depends on many indicators: the load of the bushes with eyes and shoots, the fruiting coefficient, the average mass of the bunch, the number of bushes per hectare and the agrotechnical measures.

Varieties - Adreuli shavi and Nakutvneuli had a very high calculated yield (more than $17 \mathrm{t} / \mathrm{ha}$ ). High yield (12-17 t / ha) had Goruli mtsvane and Hotsa tsibi varieties. Medium yield (from 9 to $12 \mathrm{t} / \mathrm{ha}$ ) was observed in varieties Latsu kere, Grdzelmtevana, Grubela, Amlakhu, Sibirkovyij, Vernakhi and Krasnostop zolotovskij. Low and very low yields were noted for the varieties Mahbor tsibil and Mudzhuretuli (respectively). Estimated yield indicators are shown in Figure 2. 


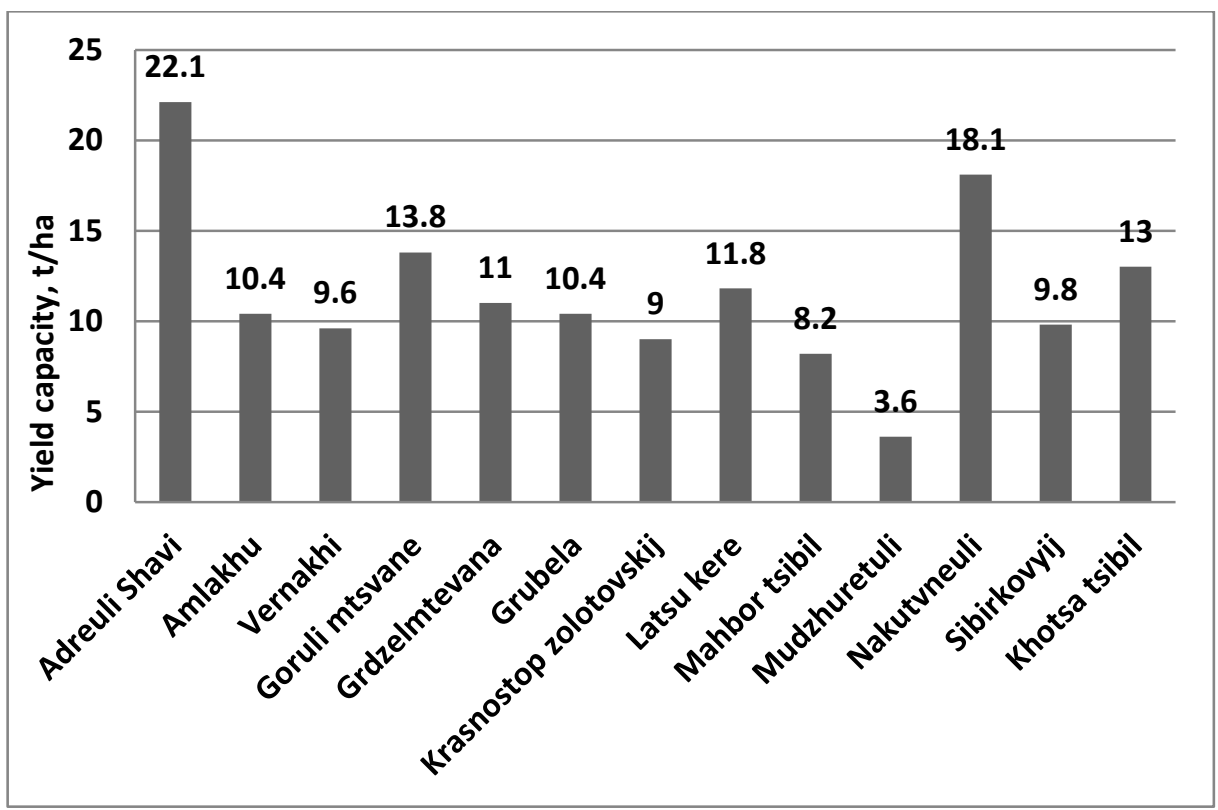

Fig. 2. The yield of studied varieties from the collection (the average for the years 2016-2019)

The quality of the harvest depends on the content of sugars and organic acids in the grapes during the period of their full ripening. The level of accumulation of sugars in berries is directly influenced by the genetic characteristics of a variety, natural and climatic conditions of the place of growth, environmental factors and the level of agricultural technology. The ratio of the amount of precipitation and the total air temperature during the growing season also have a great influence on the sugar content and titratable acidity.

Very high (over $\left.23 \mathrm{~g} / 100 \mathrm{~cm}^{3}\right)$ and high $\left(21-23 \mathrm{~g} / 100 \mathrm{~cm}^{3}\right)$ sugar content of berry juice was noted in 7 studied grape varieties: Krasnostop zolotovskij - 24.9, Grdzelmtevana - 23.4, Amlakhu - 22.6, Mudzhuretuli - 21.9, Goruli mtsvane - 21.6, Hotsa tsibil - 21.4, Sibirkovyij - $21.3 \mathrm{~g} / 100 \mathrm{~cm}^{3}$. The lowest sugar content in the juice of berries was in the Adreuli shavi variety $-17 \mathrm{~g} / 100 \mathrm{~cm}^{3}$ with an increased titratable acidity of $10 \mathrm{~g} / \mathrm{dm}^{3}$. The titratable acidity was the highest in the Vernakhi variety $-11.4 \mathrm{~g} / \mathrm{dm}^{3}$, in the other studied varieties - in the range from 5.2 (Latsu kere) to $8.2 \mathrm{~g} / \mathrm{dm}^{3}$ (Hotsa tsibil).

All studied varieties have passed the technological assessment. Dry wines from the control varieties Krasnostop zolotovskij and Sibirkovyij received high tasting marks: 8.98.8 points, respectively (on a 10-point scale). At the level or slightly below the control varieties, the grades were for wines from the varieties: Grubela - 8.8 points, Goruli mtsvane, Hotsa tsibil, Latsu kere - 8.7 points, Grdzelmtevana, Nakutvneuli - 8.6 points. Wines from the varieties - Adreuli shavi, Amlakhu, Vernakhi, Mahbor tsibil, Mudzhuretuli - got 8.5 points.

\section{Conclusions}

The studied autochthonous Georgian and Dagestan grapevine varieties adapted well in the conditions of the Rostov region. Based on the carried out studies, their agrobiological and technological characteristics were established. White technical grape varieties - Goruli mtsvane, Grdzelmtevana, Grubela, Latsu kere, Hotsa tsibil and Nakutvneuli among the red wine ones, were identified as promising due to economically valuable traits and high 
quality of wine production. These varieties are also recommended to be used in breeding for creating varieties with high technological properties for high-quality winemaking.

\section{References}

1. N. I. Dzyubenko, Herald of the Russian Academy of Sciences, 85(1), 15-19 (2015) doi: 10.1134/S1019331615010013

2. O. Failla, Vitis, 54, 1-4 (2015)

3. M. Dallakyan, E. Zyprian, E. Maul, A. Yesayan, N. Hovhannisyan, Vitis (Special Issue), 54, 23-26 (2015)

4. V. Ferreira, O. Pinto-Carnide, T. Mota, J. P. Martín, J. M. Ortiz, I. Castro, Vitis (Special Issue), 54, 53-58 (2015)

5. E. T. Ilnitskaya, I. I. Suprun, L. G. Naumova, S. V. Tokmakov, V. A. Ganich, Vavilov Journal of Genetics and Breeding, 21(6), 617-622 (2017) doi: 10.18699/VJ17.277.

6. G. Zdunić, E. Maul, J. E. J. Eiras Dias, G. Muñoz Organero, F. Carka et al., Vitis, 56(3), 127-131 (2017) https://doi.org/10.5073/vitis.2017.56.127-131

7. E. T. Ilnitskaya, S. V. Tokmakov, I. I. Suprun, L. G. Naumova, V. A. Ganich, Agricultural Biology, 51(1), 60-67 (2016) doi:10.15389/agrobiology.2016.1.60eng

8. Y. Vafaee, N. Ghaderi, A. Khadivi, Scientia Horticulturae, 225(11), 771-782 (2017) doi.org/10.1016/j.scienta.2017.08.007.

9. Y. Boz, M. Bakir, B. P. Çelikkol et al., Vitis. 50(3), 99-106 (2011)

10. D. L. Guo, Q. Zhang, G. H. Zhang, Czech J. Genet. Plant Breed., 49, 164-170 (2013)

11. S. Goryslavets, V. Risovannaya, E. Memetova et al., Vitis - Journal of Grapevine Research, 54(1), 37-41 (2015)

12. R. Basheer-Salimia, S. Lorenzi, F. Batarseh et al., Molecular biotechnology, 56(6), 546-556 (2014)

13. D. Maghradze, L. Rustioni, A. Scienza, O. Failla, Journal of the American Pomological Society, 66(2), 56-67 (2012)

14. D. Maghradze, L. Vashakidze, E. Abashidze et al., Acta Hortic. 1032, 235-242 (2014) doi: 10.17660/actahortic.2014.1032.33

15. D. Maghradze, L. Rustioni, A. Scienza, O. Failla, J.Amer.Pomolog.Soc. 66, 56-67 (2012) 